\title{
Auditor's perceptions of financial reporting quality: the case of Greece
}

\author{
Stergios Tasios (Corresponding author) \\ Dept. of Business Administration, University of the Aegean \\ 8 Michalon str., 82100, Chios, Greece \\ Tel: +30-22710-35170Ｅ-mail: stasios@ba.aegean.gr \\ Michalis Bekiaris \\ Dept. of Business Administration, University of the Aegean \\ 8 Michalon str., 82100, Chios, Greece \\ Tel: +30-22710-35170Ｅ-mail: m.bekiaris@aegean.gr
}

Received: January 11, 2012 Accepted: February 12, 2012 Doi:10.5296/ijafr.v2i1.1286

\begin{abstract}
According to IASB a key prerequisite for quality in financial reporting is the adherence to the objective and the qualitative characteristics of financial reporting information. Qualitative characteristics are the attributes that make financial information useful and consist of relevance, faithful representation, comparability, verifiability, timeliness and understandability. This paper aims to investigate auditor's perceptions of the quality of financial reports based on the qualitative characteristics of financial reporting information defined by IASB in its conceptual framework. In addition, it aims to identify the key factors that influence and improve the quality of financial reports, as well as the factors that lead to poor quality. Finally, an effort is made to assess the quality of financial reporting of Greek companies according to each qualitative characteristic of financial reporting information. Results indicate that auditors perceive the qualitative characteristics of financial reporting information as important quality elements of financial reports. As far as the quality of financial reports of Greek companies is concerned auditors perceive it to be of moderate quality attributed mainly to earnings management, poor corporate governance, family ownership and deviation from accounting principles.
\end{abstract}

Keywords: Financial reporting, quality, qualitative characteristics. 


\section{Introduction}

Financial reporting is a two party transaction in which the issuers of the financial reports provide them to the users, who use them with the expectation that these will help them enhance their financial decisions. The potential users of financial reports vary widely and include creditors, suppliers, financial analysts, government authorities and in general, all related to the company parties. The issue of quality in financial reports is of prime concern not only for the final users but for the whole society as it affects economic decisions which may have significant impact. This was verified by the most evident way by a series of corporate failures (Enron, Parmalat etc.), collapses of financial institutions (Lehman Brothers, Fortis, AIG etc.) and overall, by the economic conditions created by the recent economic recession.

As a response to the need for improvement and convergence of existing financial reporting frameworks of IASB and FASB, IASB issued in 2008 an exposure draft titled "An improved conceptual framework for financial reporting". According to IASB's conceptual framework a key prerequisite for quality in financial reporting is the adherence to the objective and the qualitative characteristics of financial reporting information, (IASB 2008). Qualitative characteristics are the attributes that make financial information useful and comprise of relevance, faithful representation, comparability, verifiability, timeliness and understandability.

The primary objective of this paper is to investigate auditor's perceptions towards financial reporting quality based on the aforementioned qualitative characteristics of financial reporting information. Furthermore, it aims to identify the key factors that affect the quality of financial reports, improve or lead to poor quality, to depict existing problems and provide insights to the quality of financial reporting of Greek companies preparing their financial statements under IFRS. For this purpose a questionnaire survey was conducted on 104 certified public accountants in Greece.

The remainder of the paper is organized as following: part two presents a literature review that includes an overview and definition of key terms, including a reference on the qualitative characteristics of financial reporting information. In addition, the measurement methods that are used to assess the quality of financial reports are presented in this section. Research design and empirical findings of the questionnaire survey are presented in part four. Finally, a summary of results and conclusions, as well as proposals for future research are presented in the last part of the paper.

\section{Literature review}

\subsection{Overview and definition of key terms}

Jonas and Blanchet (2000) describe two general perspectives that are widely used in the assessment of financial reporting quality. The first perspective relies on the needs of users. Under this perspective, quality of financial reporting is determined on the basis of the usefulness of the financial information to its users, (Baxter 2007). The second perspective of financial reporting quality is focused on the notion of shareholder/investor protection. The 
user needs perspective is mainly concerned with the provision of relevant information to users for making decisions, whereas the shareholder/investor protection perspective aims to ensure that the information provided to users is sufficient for their needs, transparent and competent, (Jonas \& Blanchet 2000).

As the subject of quality in financial reports is broad several definitions of the term financial reporting quality have been expressed, based on the objectives of each research. For instance Verdi (2006), defines financial reporting quality as "the precision with which financial reports convey information about the firm's operations, in particular its cash flows, in order to inform equity investors". Other researchers define financial reporting quality as "the extent to which the financial statements provide true and fair information about the underlying performance and financial position”, (Q. Tang et al. 2008). However, a commonly accepted definition is provided by Jonas and Blanchet (2000), who state that "...quality financial reporting is full and transparent financial information that is not designed to obfuscate or mislead users".

IASB (2006, 2008), states that "the objective of financial reporting is to provide financial information about the reporting entity that is useful to present and potential equity investors, lenders and other creditors in making decisions in their capacity as capital providers". Accordingly, AICPA (1970), defines the purpose of financial accounting and financial statements as "the provision of quantitative financial information about a business enterprise useful to the statement users". The role however of financial reporting is broader and "aims to provide evenhanded financial and other information that together with information of other sources facilitates the efficient functioning of capital and other markets and assists the efficient allocation of the scarce resources in the economy", (FASB 1978). The concept of financial reporting quality is therefore broad and includes financial information, disclosures and non financial information useful for decision making.

Financial reports should meet certain qualitative criteria in order to avoid poor quality and accomplish their purpose. Both boards of IASB and FASB in their conceptual framework conclude that high quality is achieved by adherence to the objective and the qualitative characteristics of financial reporting information, (IASB 2008). Qualitative characteristics are "the attributes that make the financial information useful and are distinguished as fundamental or enhancing depending on the way they affect the usefulness of the information", (IASB 2008). Fundamental qualitative characteristics consist of relevance and faithful representation:

- Relevance is defined as "the capability of making a difference in the decisions made by the users in their capacity as capital providers", (IASB 2008). Reported information therefore is useful only if it relates to the issues that are of prime concern to the users.

- Faithful representation is attained when "the depiction of the economic phenomenon is complete, neutral and free from material error" (IASB 2008). The phenomena to be presented are "economic resources, obligations and the transactions and events that change those resources and obligations", (FASB 1980).

Enhancing qualitative characteristics are "complementary to the fundamental qualitative 
characteristics and distinguish more useful from less useful information”, (IASB 2008). Enhancing qualitative characteristics comprise of comparability, verifiability, timeliness and understandability and their definition according to IASB's conceptual framework is the following:

- Comparability is "the quality of information that enables users to identify similarities and differences between two sets of economic phenomena".

- Verifiability is "a quality of information that helps assure users that information faithfully represents the economic phenomena that it purports to report".

- Timeliness refers to "having information available to decision makers before it loses its capacity to influence decisions".

- Understandability is "the quality that enables users to comprehend its meaning". Information that users do not understand is not useful even in the case it is relevant.

\subsection{Measurement of financial reporting quality}

A key issue that impacts directly to the nature of research in financial reporting quality is the measurement of the quality of financial reports. A useful categorization of measurement tools is provided by Van Beast et al. (2009) who identify four broad and not restrictive categories: accrual models, value relevance models, specific elements of financial reports and methods that operationalize the qualitative characteristics. While numerous research efforts have been made in the first three categories, research combining all qualitative characteristics in the assessment of financial reporting quality is limited with most research efforts focusing on one or more qualitative characteristics.

Accrual methods are based on the concept of earnings management. Earnings management is the "purposeful intervention in the external financial reporting process, with the intent of obtaining some private gain" (Schipper, 1989). A widely used model by many researchers is the Jones model or its modified versions. This model has been used in the literature to capture earnings management, which is viewed as an inverse measure of earnings quality (e.g., Bartov et al. 2001, Gul et al. 2003, Dowdell \& Krishnan 2004, etc.). The other frequently used proxy for earnings and accrual quality is the Dechow and Dichev (2002) accrual quality measure which is based on how well accruals map into cash flows. This measure defines accrual quality as the error variance from a regression of working capital accruals on past, current, and lagged cash flows. Many researchers have used this model or variants of it, such as Francis et al. (2004, 2005), Aboody et al. (2005), Vafeas (2005) etc.

Value relevance models are designed to assess whether particular accounting amounts reflect information that is used by investors in valuating firms' equity, (Barth 2001) and examine the association between a security price dependent variable and a set of independent accounting variables, (Beaver 2002). Holthausen and Watts (2001) classify value relevance studies in three categories: relative association studies, incremental association studies and marginal information content studies. Relative association studies focus on the relationship between stock market values or returns and various accounting numbers, based on standard regression techniques. Incremental association studies utilize regression models in order to examine if 
an accounting variable is useful in explaining value or return over a long time period, usually given several other variables. Marginal information content studies are concerned with the relationship between return or abnormal return and investor's available set of information. The most frequently employed model in value relevance research is based on Ohlson, (1995) and its subsequent modifications (Feltham \& Ohlson 1996, Ohlson 1999, etc.). Many empirical studies were affected by this model, examples of which include Burgstahler and Dichev (1997), Aboody et al. (2002), etc.

Research in specific elements of financial reports include measurement tools that focus on both financial and non financial information of the annual reports and examine the influence of specific information of the reports on the decisions of the users, (Van Beest et al. 2009). Research examples in this area include the examination of restatements in the financial statements (e.g. Palmrose et al 2004, Plumlee \& Yohn 2008), the use of narratives in the annual reports (e.g. Beattie et. al. 2004), the use of graphs in the annual reports (e.g. Beattie \& Jones 2002, Penrose 2008), content analysis examining the letters from the president or the CEO in the annual reports (e.g. Kohut \& Segars 1992, Fisher \& Hu, 1989), examination of auditor's report or qualifications (e.g. Caramanis 2006), going concern issues (e.g. Martens D. et al. 2008) etc. It is evident that the focus of interest in this category varies widely depending on which element of the financial reports is surveyed by the researcher.

Methods that operationalize qualitative characteristics aim to assess the qualities of different aspects and dimensions of financial and non financial information of financial reports in order to determine their usefulness, (Van Beest et al., 2009). This is achieved through the use of indexes or questionnaires created to capture the qualities of the qualitative characteristics which were described above (i.e. relevance and faithful presentation, comparability, verifiability, timeliness, understandability). Examples of this stream of research include Jonas and Blanchet (2000), Lee et al. (2002), Mc Daniel et al. (2002), Daske H. and Gebhart (2006), Callao et al (2007) etc. Most of the research in this category has studied either one or more qualitative characteristic individually, with the exception of Van Beest et al. (2009) who combined all qualitative characteristics in one study, incorporating them in a financial reporting quality index.

Finally, as far as the case of Greece is concerned research is mainly focused in the three first categories of measurement tools: value relevance, accrual models and specific elements of financial statements, (i.e. Baralexis 2004, Tsalavoutas et al 2007, Koumanakos Dimitropoulos et al 2009). Main findings indicate that Greek companies manage their earnings, that there is room for improvement in financial disclosures and that reporting quality improved after the adoption of IFRS. Research regarding the qualitative characteristics of financial reporting in Greece is limited and no research has been conducted yet to examine the perceptions of auditors or other categories of professionals towards these qualitative characteristics.

\section{Research design}

\subsection{Questionnaire}




\section{MInstitute ${ }^{\text {Mnk }}$}

The questionnaire of the survey consists of three parts. Key terms regarding the qualitative characteristics of financial reports were provided in the beginning of the questionnaire in order to enhance the understanding of the participants towards the subject of the research. The first part aims to capture the significance of each qualitative characteristic of financial reporting information, of the factors that affect the quality of financial reports and of non financial characteristics of financial reporting, using a five point Likert scale. Moreover, each participant was asked to provide a general assessment of the quality of financial reports of Greek companies including reporting through the web, the significance of the factors that lead to low quality and of the factors which could improve reporting quality. Finally, participants were asked their opinion regarding the adoption of IFRS, the impact of the financial crisis and to provide their own definition of the term "financial reporting quality".

The second part of the questionnaire aims to provide deeper insights on the views of the participants through questions relating to each qualitative characteristic of financial reporting information, incorporating questions based on the financial reporting index developed by Van Beest et al. (2009). The third part of the questionnaire includes questions about the demographic characteristics of the participants (sex, age, profession, studies, years of working experience, professional qualification). Finally, the option to write comments was given to the participants in order to express their opinion on the subject and provide their feedback on the survey.

\subsection{Pilot testing}

Prior to distribution the questionnaire was subjected to pilot testing that included three professionals with significant experience in the area of accounting and finance: one certified public accountant, one financial accountant and one financial analyst. Based on feedback provided by the review and the comments of the participants the content, wording and structure of the questionnaire was improved reaching its final form.

\section{Empirical results}

\subsection{Survey background}

The population of certified public accountants (CPA's) in Greece amounted at the period of the survey according to the records of the Hellenic Institute of Certified Public Accountants (HIPCA) to 738 members (March 2011, data). The questionnaire was developed and administered through Lime Survey application, available by the University of the Aegean. None of the known sampling methods of data collection was implemented, as the whole population of the Greek auditors was used. The questionnaire was sent by e-mail to 654 auditors. The mail was chosen as the method of questionnaire distribution instead of face-to-face or telephone interview because (a) it is easier than other methods for the participants, as they had the opportunity to fill out the questionnaire whenever they wanted; (b) it is cheaper than the other methods; and (c) the participants were not influenced by the researchers.

602 e-mails were delivered with 52 mail delivery failures attributed to various reasons (i.e non valid e-mail addresses, blocked from company servers etc.). 50 participants followed the 
option given through the e-mail not to participate. Taking into account the aforementioned exceptions population amounts to 552 CPA's of whom 170 answered questionnaires were received leading to a response rate of $30,79 \%$, which is higher than the ample response rate (i.e. 15-20 per cent) for a questionnaire survey, (Standen, 1998). Fully completed and useable questionnaires amounted to 104 which represent $14,09 \%$ of the total population of CPA's in Greece registered in HICPA.

A non response bias test was performed using t-test between early and late respondents. The assumption of non response bias test is based on the concept that the respondents who respond less readily and late are like non respondents and hence consist a proxy for non responses, (Salleh et al., 2001). More specifically we examined the following hypothesis:

$\mathrm{H}_{0}$ : there is no difference between the respondents who answer the questionnaire late or rapidly

versus

$\mathrm{H}_{1}$ : differences exists between these two groups of respondents

$\mathrm{T}$ - test was applied, (level of statistical significance $\mathrm{a}=0,05$ ). The results of the test showed no significant differences between early and late respondents and therefore existence of non response bias is improbable. Likewise there are no significant differences between the first 52 and the last 52 responses received or between the first and last half of the responses received, providing evidence against non response bias.

\subsection{Reliability test}

Questionnaires were subject to a reliability test of internal consistency using Cronbach's a. Cronbach's a amounts to 0.886 indicating that the measures are reliable, (number of cases 104, number of items 74).

\subsection{Respondent's background}

Analysis of the demographic data showed that about 80 percent of the respondents were male and 20 percent female. 51 per cent were aged between 31 and 40 years old, 22 percent between 51 and 60 years old and 21 percent between 41 and 50 years old. Respondents consist of highly experienced professionals as 79 percent have more than 10 years of professional experience of whom approximately half of them exceed 20 years. As far as the academic background is concerned all respondents have a bachelor degree and more than half of them (55 percent) a master's degree. The examination of the studies of the respondents showed that 42 percent are in the field of accounting, 24 percent in economics and 21 percent in business administration. From the demographic data presented above, we conclude that participants of the survey are experienced, specialized, qualified and therefore appropriate to provide their opinion on the questionnaire.

\subsection{Results and discussion}

The majority of the questionnaire used a five point Likert Scale in order to provide a measure of the perceptions of the auditors towards financial reporting quality. The sequence of the 
questionnaire was arranged in order of topic and not randomly dispersed so that the subjects would concentrate on each qualitative characteristic providing consistent and focused response. Respondents were asked to provide a response rate on scale of 1 to 5 , with low numbers representing minimum amounts and high numbers maximum amounts. Interpretation of the results is based upon the average mean values of the response to each individual item, in the case of the responses were the Likert scale was utilized. The higher the average mean the greater the importance or higher the degree in the response of the question.

\subsubsection{First part of the questionnaire: overview of financial reporting}

The first part of the questionnaire consists of ten questions and aims to provide an overall view on the subject under examination.

The first question that the auditors were asked to answer was the importance of the qualitative characteristics of financial reporting, (table 1).

Table 1: Importance of qualitative characteristics

\begin{tabular}{|l|l|l|}
\hline Characteristic & Mean & Variance \\
\hline Relevance & 4.29 & 0.654 \\
\hline Faithfull representation & 4.53 & 0.815 \\
\hline Comparability & 4.46 & 0.523 \\
\hline Verifiability & 4.18 & 0.830 \\
\hline Timeliness & 4.07 & 0.937 \\
\hline Understandability & 4.44 & 0.793 \\
\hline
\end{tabular}

Auditors perceive all qualitative characteristics as very important quality elements of financial reports with higher perceived importance on faithful representation and comparability and lower to timeliness. This is consistent with the definition of financial reporting quality given by most the respondents, who used the term "to represent faithfully the financial position" in their comments on the non mandatory field in which they were asked to give their own definition of financial reporting quality.

The second question of the questionnaire referred to the importance of non financial characteristics of financial reports, (table 2).

Table 2: Importance of non financial characteristics of financial reporting

\begin{tabular}{|l|l|l|}
\hline Characteristic & Mean & Variance \\
\hline Diagrams & 2.86 & 0.979 \\
\hline Letter of president/CEO & 3.62 & 1.521 \\
\hline Narratives & 4.15 & 0.753 \\
\hline Pictures & 2,44 & 1,065 \\
\hline Notes & 4,55 & 0.580 \\
\hline
\end{tabular}

According to the results presented in table 2, auditors perceive notes and narratives of financial reports as important elements of non financial information for quality in financial 
reporting. On the other hand diagrams and pictures are considered as less important characteristics. This could be attributed to the fact that pictures and diagrams are not included in the scope of statutory audits conducted by CPA's, in contrary to the notes of the financial statements.

The next question of the survey requested from respondents to assess the effect of a list of factors on the quality of financial reporting, the results of which are presented in table 3.

Table 3: Importance of factors for quality in financial reports

\begin{tabular}{|l|l|l|l|l|l|}
\hline Factor & Mean & Variance & Factor & Mean & Variance \\
\hline Firm size & 4.02 & 0.951 & Independence of BoD & 4.17 & 1.212 \\
\hline Industry & 3.41 & 0.983 & Audit committee & 4.01 & 0.942 \\
\hline Profitability & 3.20 & 1.153 & Internal audit & 4.09 & 1.012 \\
\hline Leverage & 3.39 & 0.765 & Training of personnel & 4.22 & 0.718 \\
\hline Company age & 2.75 & 0.985 & $\begin{array}{l}\text { Supervision/ audit of } \\
\text { public authorities }\end{array}$ & 4.33 & 0.794 \\
\hline Listing in capital market & 4.24 & 1.019 & $\begin{array}{l}\text { Reporting through the } \\
\text { company's internet site }\end{array}$ & 3.82 & 1.005 \\
\hline Accounting firm & 4.18 & 0.986 & & & \\
\hline
\end{tabular}

Auditors perceive most of the factors presented in table to exert significant influence on the quality of financial reports, (mean>4). Most significant factors (factors with higher mean), are considered to be the listing of a company in a capital market, supervision and audits performed by the public authorities, training of personnel, the accounting firm who performed the audit and independence of the members of the board of directors. Auditors find factors like company age, profitability and leverage as less important quality factors of financial reporting.

The opinion of the auditors regarding the quality of the financial reports of Greek companies is presented in table 4 that follows.

Table 4: Quality of financial reporting of Greek companies

\begin{tabular}{|l|l|l|}
\hline Characteristic & Mean & Variance \\
\hline Relevance & 3.13 & 0.576 \\
\hline Faithfull representation & 3.13 & 0.739 \\
\hline Comparability & 3.39 & 0.523 \\
\hline Verifiability & 2.97 & 0.669 \\
\hline Timeliness & 3.33 & 0.902 \\
\hline Understandability & 3.18 & 0.597 \\
\hline Overall assessment & 3.13 & 0.072 \\
\hline
\end{tabular}

According to the results of table 4 auditors perceive financial reporting quality of Greek companies to be moderate (average value is close to 3, in the 5 point Likert scale) both in each qualitative characteristic individually, as well as in the overall assessment, (average 
value 3.13). Further insights to the issue of quality of financial reporting of Greek companies and an understanding for this score is provided through questions 6 and 7 which investigate factors that lead to poor quality and factors that could improve quality of financial reports and through the questions of the second part of the questionnaire.

The fifth question of the survey inquired auditors opinion regarding the quality of financial reporting through the internet, (table 5).

Table 5: Quality of financial reporting of Greek companies provided through internet

\begin{tabular}{|l|l|l|}
\hline Characteristic & Mean & Variance \\
\hline Relevance & 3.13 & 0.538 \\
\hline Faithfull representation & 3.25 & 0.655 \\
\hline Comparability & 3.35 & 0.714 \\
\hline Verifiability & 2.97 & 0.766 \\
\hline Timeliness & 3.43 & 0.947 \\
\hline Understandability & 3.16 & 0.643 \\
\hline Overall assessment & 3.18 & 0.578 \\
\hline
\end{tabular}

Auditors perceive the quality of financial reporting of Greek companies provided through the internet (i.e. company's site) to be moderate both individually to each qualitative characteristic and in the overall assessment as well. Results of this question are consistent with the results of the previous question who examined overall quality of financial reporting of Greek companies.

The next two questions investigated auditor's views towards factors that lead to poor financial reporting quality and factors that could improve quality. The main factors that auditors believe that lead to poor quality in financial reporting are earnings management $(23,52 \%$ of responses), poor corporate governance $(14,7 \%)$, deviation from accounting principles $(11,76 \%)$, insufficient supervision/ audit from public authorities, and family ownership $(11,76 \%)$.

On the other hand the main factors that could improve financial reporting quality are a stringent supervisory framework $(18,72 \%)$, audit of the quality of the audits performed by accounting firms $(17,73 \%)$ and training of company's personnel $(17,73 \%)$ which many respondents in their comments think that is insufficient. The finding that the main factor that leads to poor quality in the financial reporting of Greek companies is earnings management verifies the results of other surveys conducted in Greece which found indications that Greek companies manage their earnings, (i.e. Koumanakos).

Finally, participants were asked to provide their opinion on the impact of the adoption of IFRS in Greece and of the economic crisis on financial reporting quality, (table 6).

Table 6: Impact of IFRS adoption and of the economic crisis

\begin{tabular}{|l|c|c|c|c|c|}
\hline & Very negative & Negative & Neutral & Positive & Very positive \\
\hline Impact of IFRS adoption & 1.92 & 18.27 & 9.62 & 45.19 & 25.00 \\
\hline
\end{tabular}




\begin{tabular}{|l|l|l|l|l|l|}
\hline Impact of economic crisis & 5.77 & 47.12 & 32.69 & 14.42 & 0 \\
\hline
\end{tabular}

The majority of the respondents $(52,89 \%)$, believe that the economic crisis had negative to very negative impact on the quality of financial reports. On the contrary, the transition to IFRS reporting is perceived that it had positive to very positive impact $(80,15 \%)$. This conclusion agrees with the findings of studies conducted on the impact of the adoption of IFRS in Greece who found that it improved the quality of financial reports (i.e. Tsalavoutas). An interesting finding that needs further investigation however, is that a significant number of auditors (approximately 20\%) believe that IFRS adoption had a negative impact.

Several respondents in their comments believe that key problems in the area of financial reporting in Greece relate to the estimations made by management in the preparation of the financial statements and valuations performed by experts (i.e actuary reports, valuations of buildings etc.), which, in their opinion, in some cases are prepared according to management instructions. Another significant problem on which auditors focus their attention is the training of companies' personnel which is considered insufficient in the area IFRS and to the importance of IFRS for SME's, which could be useful in the case of Greek companies due to their size.

\subsubsection{Second part of the questionnaire: assessment of financial reporting quality}

The second part of the questionnaire aims to provide further insights on the issue of financial reporting quality utilizing questions according to each qualitative characteristic of financial reporting information. Several questions of this part were adopted from the items of the financial reporting quality index developed by Van Beest et al (2009) with the objective to capture the perceived quality of the reports of Greek companies. Questions in this section of the questionnaire are arranged in order of each qualitative characteristic and responses were provided in a five point Likert scale except for the cases defined otherwise. The questions of this part of the questionnaire were the following:

Relevance

Q1: To what extent the presence of forward looking statements helps the development of expectations and predictions by the users regarding the future?

Q2: To what extent the presence of non financial information in terms of business opportunities and risks complement the financial information?

Q3: To what extent reported earnings provide feedback to the users of the annual reports regarding how various events and significant transactions affected the company?

Faithfull representation

Q4: To what extent are valid and sufficient substantiation provided regarding assumptions and estimates (i.e. actuarial reports, valuations etc.) in the preparation of the financial statements?

Q5: To what extent accounting principles are firmly followed?

Q6: To what extent financial reports highlight positive as well as negative events?

Q7: To what extent do companies provide information regarding corporate governance?

Comparability 


\section{Macrothink}

Q8: To what extent the notes referring to changes in accounting policies explain the effect of these changes?

Q9: To what extent revisions of the financial statements explain the implications of the revision?

Q10: To what extent comparative data is provided regarding previous accounting periods?

Q11: To what extent information provided in annual reports is comparable to the information provided by other organizations of the same industry?

Q12: To what extent analysis of financial ratios and other indexes supports the comparability of financial reporting?

Verifiability

Q13: To what extent provided information is verifiable?

Timeliness

Q14: To what extent financial reports are provided timely to the users?

Understandability

Q15: To what extent the information of financial reports is presented in an organized manner?

Q16: To what extent the notes of the financial statements are clear and understandable?

Q17: To what extent graphs, pictures and tables enhance the understanding of presented information?

Q18: To what extent technical and other terms of the financial statements are understandable? The results of the above questions are presented in table 7, which includes per question, the mean and variance of the response and per qualitative characteristic the average values of the means.

Table 7: means, variances and average values

\begin{tabular}{|l|l|l|}
\hline Item & Mean & Variance \\
\hline Relevance & & \\
\hline Q1 & 3.14 & 1.134 \\
\hline Q2 & 3.45 & 0.852 \\
\hline Q3 & 3.30 & 0.871 \\
\hline Average & 3.30 & \\
\hline Faithfull representation & & \\
\hline Q4 & 3.09 & 0.857 \\
\hline Q5 & 3.29 & 0.654 \\
\hline Q6 & 2.88 & 1.152 \\
\hline Q7 & 2.38 & 0.588 \\
\hline Average & 2.91 & \\
\hline Comparability & & \\
\hline Q8 & 3.08 & 0.751 \\
\hline Q9 & 3.09 & 0.740 \\
\hline Q10 & 2.01 & 0.010 \\
\hline Q11 & 2.58 & 1.043 \\
\hline
\end{tabular}




\begin{tabular}{|l|l|l|}
\hline Q12 & 3.49 & 0.757 \\
\hline Average & 2.85 & \\
\hline Verifiability & & \\
\hline Q13 & 2.77 & 0.626 \\
\hline Timeliness & & \\
\hline Q14 & 3.29 & 0.712 \\
\hline Understandability & & \\
\hline Q15 & 3.28 & 0.591 \\
\hline Q16 & 3.24 & 0.650 \\
\hline Q17 & 3.16 & 0.624 \\
\hline Q18 & 2.88 & 0.829 \\
\hline Average & 3.14 & \\
\hline
\end{tabular}

The results of this part of the questionnaire indicate a moderate quality of financial reporting of Greek companies, which is consistent with the overall assessment provided through the first part of the questionnaire. In particular average values were for relevance 3.30, for faithful representation 2.91, for understandability 3.14 , for comparability 2.85 , for timeliness 3.29 and for verifiability 2.77. Corresponding values for each qualitative characteristic according to the first part of the questionnaire were 3.13, 3.13, 3.18, 3.39, 3.29, 2.97 and do not vary significantly from the findings of the second part of the questionnaire.

The lower values were observed for questions 7 (2.38), which indicates a low degree in the information relating to corporate governance, question 10 (2.01), a low degree of comparative data regarding previous accounting periods, and question 11 (2.58), a low degree of comparability with companies of the same industry. On the other hand the higher degrees were observed for questions 2 and 12, indicating a moderate degree of the feedback provided by reported earnings to the users of the annual reports and a moderate degree of support of financial ratios and other indexes to the comparability of financial reporting.

\section{Conclusion}

Financial reporting quality is a key prerequisite for the effective functioning of the economy. In order to fulfill their primary objective, which is to facilitate economic decision making without misleading or obfuscate the users, financial reports should meet certain qualitative characteristics. These characteristics are divided by IASB into two categories: fundamental and enhancing. Fundamental characteristics consist of relevance and faithful representation. Enhancing characteristics comprise of comparability, verifiability, timeliness and understandability.

Various methods have been used to assess the quality of financial reporting which can be categorized in four broad categories: accrual methods, value relevance models, specific elements of financial reports and methods that operetionalize the qualitative characteristics. Accrual methods and value relevance models focus on the earnings dimension of financial reporting. Measurement methods that focus on specific elements examine the influence of specific information of the reports on the decisions of their users. Finally, methods that 
operationalize qualitative characteristics are considered more efficient and aim to assess the qualities of different aspects and dimensions of financial and non financial information of the financial reports in order to determine their usefulness.

The main objective of this survey was to investigate auditor's perceptions of the quality of financial reports based on the qualitative characteristics of financial reporting information defined by IASB in its conceptual framework. Findings indicate that auditors perceive qualitative characteristics as important quality factors of financial reports, considering faithful representation as the most important of them. Accordingly, notes and narratives are perceived as important non financial characteristics of financial reports. Most significant factors that affect the quality of financial reports are considered to be the listing of a company in a capital market, supervision and audits performed by the public authorities, training of personnel, the accounting firm who performed the audit and independence of the members of the board of directors.

The quality of financial reporting provided by the financial reports of Greek companies and through the internet is perceived to be moderate. The main factors that auditors believe that lead to poor quality in financial reporting are earnings management, poor corporate governance, deviation from accounting principles, insufficient supervision/ audit from public authorities, and family ownership. On the other hand the main factors that could improve financial reporting quality are a stringent supervisory framework, audit of the quality of the audits performed by accounting firms and training of companies' personnel, which many respondents in their comments think that is insufficient. As far as the impact of the financial crisis and the adoption of IFRS is concerned auditors believe that the financial crisis had a negative impact on the quality of financial reporting and the transition to IFRS a positive impact. Finally, future research will include accountants as preparers of the financial statements and credit officers as the primary users in order to investigate their perceptions as well and provide a wider view on the subject.

\section{References}

Aboody D., Hughes, J. and Liu J. (2002), Measuring value relevance in a (possibly) inefficient market, Journal of Accounting Research, 40(2), pp. 965-984.

Aboody D., Hughes, J. and Liu J. (2005), Earnings quality, insider trading and cost of capital, Journal of Accounting Research, vol. 43, no. 5, pp. 651-673.

AICPA, (1970), APB statement no 4, Basic Concepts and Accounting Principles Underlying Financial Statements of Business Enterprises, (cited in Rosenfield, 2006).

Baralexis S, (2004), Creative accounting in small countries: the Greek case, Managerial Auditing Journal, Vol 19, No 3, pp 440 - 461.

Barth E, Beaver H, \& Landsman R. (2001). The value relevance of value relevance literature for financial accountant standard setting: another view. Journal of accounting and economics, $31,77-104$.

Bartov, E., Gul, F. \& Tsui, J. (2001), Discretionary - accruals models and audit qualifications, 
Journal of Accounting and Economics, vol. 30, no. 3, pp. 421-452.

Baxter (2007), Audit Committees and financial reporting quality, PhD Dissertation Thesis, University of Queensland, Australia.

Beaver H. (2002), Perspectives on recent capital research, The accounting review, 77(2), pp. 453-474.

Beattie V. \& Jones M.J., (2002), Measurement distortion of graphs in corporate reports: An experimental study, Accountancy, Auditing and Accountability Journal, 15(4), 546-564.

Beattie V. \& McInnes W., (2004), A methodology for analyzing and evaluating narratives in annual reports: a comprehensive descriptive profile and metrics for disclosure quality attributes, Accounting Forum 28(3), pp 205-236.

Beest Van F., Braam G., Boelens S. (2009), Quality of Financial Reporting: measuring qualitative characteristics, Working Paper, Nice.

Botosan C, (2004), Discussion of a framework for the analysis of risk communication. The International Journal of Accounting, 39, pp 289-295.

Burgstahler D. C. \& Dichev I. D. (1997), Earnings adaption and equity value, The accounting review, 72, 187-215.

Caramanis C and Spathis C, (2006), Auditee and audit firm characteristics as determinants of audit qualifications: evidence from Athens Stock Exchange, Managerial Auditing Journal, 21, pp 905-920.

Choi B, Collins D.W., Johnson W.B., (1997), Valuation implications of reliability differences: the case of non-pension post retirements obligations. The accounting review, 72, 351-383.

Dechow P. M., Schrand M. C. (2004), Earnings Quality, Monograph, The research foundation of CFA.

Dechow, P., Dichev, I., (2002). The quality of accruals and earnings: the role of accrual estimation errors. The Accounting Review 77 (Supplement), 35-59.

Dimitropoulos P, Asteriou D, (2008), Timeliness, conservatism and financial transparent firms under the Greek accounting setting, Review of Accounting and Finance, 7,(3), pp 253-269.

Dimitropoulos P., Asteriou D., (2009), The value relevance of financial statements and their impact on stock prices: evidence from Greece, Managerial Auditing Journal, 24,(3), pp. 248-265.

Dimitropoulos P., Asteriou D, (2009), The effect of board composition and quality of annual earnings: Empirical evidence from Greece, Research in International Business and Finance, 24,(2), pp. 190-205.

Dowdell, T. and Krishnan, J. 2004, 'Former audit firm personnel as CFOs: Effect on earnings management, Canadian Accounting Perspectives, vol. 3, no. 1, pp. 117-142. 
FASB (1978), Statement of concepts no 1, Con 1, Objectives of financial reporting by business enterprises.

FASB (1980), Statement of concepts No 2, Con 2, Qualitative characteristics of accounting information.

FASB (1985), Statement of concepts No 6, Con 6, Elements of financial statements.

Fisher F.A., \& Hu M. Y., (1989), Does the CEO's letter to the shareholders have predictive value? Business Forum 14(1), 22-24. (cited in Penrose, 2008)

Francis J., LaFond, R., Olsson, P. and Schipper, K. (2005), The market pricing of accruals quality, Journal of Accounting and Economics, vol. 39, no. 2, pp. 295-327.

Francis J., LaFond, R., Olsson, P. and Schipper, K. (2004), Cost of equity and earnings attributes, The accounting review, 79(4), 967-1010.

Feltham G. A. \& Ohlson J. A. (1996), Uncertainty resolution and the theory of depreciation measurement. Journal of Accounting Research, 34, 209-234.

Gjerde, O., K. H. Knivsfla and F. Saettan (2007), The value relevance of financial reporting on the Oslo Stock Exchange over the period 1964-2003, Discussion Paper, Norwegian School of Economics and Business Administration.

Gul, F., Chen, C. and Tsui, J. 2003, Discretionary accounting accruals, managers' incentives and audit fees, Contemporary Accounting Research, vol. 20, no. 3, pp. 441-464.

Holthausen R. W. \& Watts R.L., (2001), The relevance of value relevance literature for financial accounting standard setting, Journal of Accounting and Economics, 38,(1-3) pp $117-128$

Healy P. \& Whalen J. (1999), A review of earnings management literature and its implications for standards settings, Accounting Horizons pp. 365-383.

IASB (2008). Exposure Draft on an improved Conceptual Framework for Financial Reporting Chapter 1 \& Chapter 2.

IASB (2006). Preliminary Views on an improved conceptual framework for financial reporting.

Jonas, G. \& Blanchet, J. (2000). Assessing Quality of Financial Reporting. Accounting Horizons, 14(3). (Cited in Baxter, 2007)

Kohut F., \& Segars H., (1992), The president's letter to stockholders: An examination of corporate communication strategy, Journal of Business Communication, 29 (1), 7-22.

Koumanakos E., Georgopoulos A., \& Siriopoulos C., (2008), Auditor awareness of earnings management, International Journal of Accounting, Auditing \& Performance Evaluation, 5(1), pp. 50-65.

Koumanakos E., Georgopoulos A., \& Siriopoulos C., (2005), Firms acquisitions and earnings 


\section{Al Macrothink}

International Journal of Accounting and Financial Reporting

ISSN 2162-3082 2012, Vol. 2, No. 1

management: evidence from Greece, Managerial Auditing Journal, 20,(7), pp. 663-678..

Lee Y. W., Strong D. M., Kahn B. K. \& Wang R. Y. (2002), AIMQ: a methodology for information quality assessment. Information and Management, 40, 133- 146.

Martens D., Bruynseels L., Baesens B., Willekens M., Vanthienen J. (2008), Predicting going concern opinion with data mining, Decision Support Systems, 45, pp. 765-777.

McDaniel L., Martin R., \& Maines L., (2002), Evaluating financial reporting quality: the effects of financial expertise vs. financial literacy. The accounting review, 77, 139-167.

Ohlson J., (1999), On transitory earnings. Review of accounting studies 4, 145-162.

Penman H. S., (2003), The quality of financial statements: perspectives from the recent stock market bubble, Accounting Horizons, 17, pp 76-96.

Plumlee M., Yohn T.L., (2008), Restatements: Investor Response and Firm Reporting Choices, Working Paper.

Palmrose, Z., Richardson, V., and Scholz, S., (2004). Determinants of market reactions to restatement announcements. Journal of Accounting and Economics 37, 59-90.

Penrose M. J., (2008), Annual report graphic use: a review of the literature, Journal of business communication, 45(2), 158-180.

Rosenfield P (2006), Contemporary issues in financial reporting. A user-oriented approach. Taylor and Francis Group.

Salleh H., Narasimhan M.S., and Christopher T. (2001), Usefulness of the statement of cash flow: evidence from Indian mutual fund analysts", Asian review of accounting, Vol. 9, No 2, pp. $75-98$.

Schipper K., (1989), Commentary on earnings management, Accounting Horizons. (cited in Rosenfield 2006)

Standen C.J.V., (1998), The usefulness of the value added statement in South Africa, Managerial Finance, Vol. 24, No 11, pp. 44-59.

Tang Q, Chen H, Zhijun L, (2008), Financial reporting quality and investor protection: a global investigation, Working Paper. 


\section{Macrothink}

\section{Copyright Disclaimer}

Copyright reserved by the author(s).

This article is an open-access article distributed under the terms and conditions of the Creative Commons Attribution license (http://creativecommons.org/licenses/by/3.0/). 